\title{
Tannin components and inhibitory activity of Kakadu plum leaf extracts against microbial triggers of autoimmune inflammatory diseases
}

\author{
R. Courtney ${ }^{\mathrm{a}}$, J. Sirdaarta ${ }^{\mathrm{a}, \mathrm{b}}$, B. Matthews ${ }^{\mathrm{c}}$, I. E. Cock $\mathrm{C}^{\mathrm{a}, \mathrm{b}^{*}}$ \\ aSchool of Natural Sciences, Nathan Campus, Griffith University, 170 Kessels Rd, Nathan, Queensland 4111, Australia \\ ${ }^{b}$ Environmental Futures Research Institute, Nathan Campus, Griffith University, 170 Kessels Rd, Nathan, Queensland 4111, \\ Australia \\ 'Smartwaters Research Centre, Griffith University, Gold Coast Campus, Australia
}

\begin{abstract}
Introduction: Autoimmune inflammatory diseases can be triggered by specific bacteria in susceptible individuals. Terminalia ferdinandiana (Kakadu plum) has documented therapeutic properties as a general antiseptic agent. However, the high ascorbic acid levels in Kakadu plum fruit may interfere with this activity. Methods: $T$. ferdinandiana leaf solvent extracts were investigated by disc diffusion assay against a panel of bacteria known to trigger autoimmune inflammatory diseases. Their MIC values were determined to quantify and compare their efficacies. Toxicity was determined using the Artemia franciscana nauplii bioassay. Non-targeted HPLC separation of crude extracts coupled to high resolution time-of-flight (TOF) mass spectroscopy with screening against 3 compound databases was used for the identification and characterisation of individual components in crude plant extracts. Results: Methanolic, aqueous and ethyl acetate $T$. Ferdinandiana leaf extracts displayed potent antibacterial activity in the disc diffusion assay against the bacterial triggers of rheumatoid arthritis, ankylosing spondylitis and multiple sclerosis. The ethyl acetate extract had the most potent inhibitory activity, with MIC values less than $120 \mu \mathrm{g} / \mathrm{ml}$ against $P$. mirabilis and $A$. baylyi (both reference and clinical strains). The ethyl acetate extract had similar potency against $K$. pneumonia (both reference and clinical strains), but had higher MIC values $(2733 \mu \mathrm{g} / \mathrm{ml})$ against $P$. aeruginosa. The methanolic extract was also a potent inhibitor of bacterial growth, with MIC values generally $<1000 \mu \mathrm{g} / \mathrm{ml}$. In comparison, the water, chloroform and hexane leaf extracts were all substantially less potent antibacterial agents, with MICs values generally well over $1000 \mu \mathrm{g} / \mathrm{ml}$. All $T$. ferdinandiana leaf extracts were either nontoxic or of low toxicity in the Artemia fransiscana bioassay. Non-biased phytochemical analysis of the ethyl acetate extract revealed the presence of high levels of tannins (exifone (4-galloylpyrogallol), ellagic acid dehydrate, trimethylellagic acid, chebulic acid, corilagin, punicalin, castalagin and chebulagic acid). Conclusion: The low toxicity of the $T$. ferdinandiana leaf extracts and their potent inhibitory bioactivity against the bacterial triggers of autoimmune inflammatory disorders indicates their potential as medicinal agents in the treatment and prevention of these diseases.
\end{abstract}

Key words: Terminalia ferdinandiana, rheumatoid arthritis, ankylosing spondylitis, multiple sclerosis, Proteus mirabilis, Klebsiella pneumoniae, Acinetobacter baylyi, Pseudomonas aeruginosa.

\section{INTRODUCTION}

Autoimmune inflammatory disorders are a group of debilitating conditions including rheumatoid arthritis, ankylosing spondylitis, lupus and multiple sclerosis,

\section{${ }^{*}$ Corresponding author:}

Dr. I. E. Cock

School of Natural Sciences,

Environmental Futures Research

Institute Nathan Campus, Griffith University,

170 Kessels Rd, Nathan, Queensland 4111, Australia

E-mail: I.Cock@griffith.edu.au

DOI: $10.5530 / p j .2015 .7 .2$ which afflict genetically susceptible individuals. There is no common susceptibility profile for these disorders. Rheumatoid arthritis for example is most prevalent in middle aged to older women, whereas the onset of ankylosing spondylitis occurs most frequently in younger males. ${ }^{1}$ There are no cures for any of these conditions. Instead, current treatment strategies aim to alleviate the symptoms (particularly pain, swelling and inflammation) with analgesics and anti-inflammatory agents and/or to modify the disease process through the use of disease modifying drugs. None of these treatments is ideal as prolonged usage of these drugs is often accompanied by unwanted side effects and toxicity. ${ }^{2}$ There is a need 
to develop safer, more effective treatments for these conditions which will not only alleviate the symptoms, but may also cure or prevent the disease. A greater understanding of the onset and progression of these disorders should greatly assist in more relevant drug discovery and development.

The causes of the autoimmune inflammatory disorders are currently not well understood. However, it is generally accepted that they are immune disorders triggered in susceptible individuals by specific microbial infections. Recent serotyping studies have identified several of the bacterial triggers of these conditions and the bacterial antigens responsible for the induction of an immune response (Table 1). The major microbial trigger of rheumatoid arthritis has been identified as Proteus mirabilis, ${ }^{3}$ a normal part of the human gastrointestinal flora. Similarly, Klebsiella pneumoniae has been shown to initiate ankylosing spondylitis ${ }^{4}$ and Acinetobacter baylyi and Pseudomonas aeruginosa have been linked with the onset of multiple sclerosis. ${ }^{5}$ Borrelia burgdorferi is linked with Lyme disease. ${ }^{6}$ Whilst microbial triggers have also been postulated for lupus, the specific causative agents are yet to be identified. Similarly, members of the Enterobacteriaceae family are associated with Graves' disease and Kawasaki syndrome and Mycoplasma pneumoniae is associated with several demyelinating diseases. ${ }^{7}$ The development of antibiotic agents targeted at the specific bacterial triggers of autoimmune inflammatory disorders would enable afflicted individuals to target these microbes and thus prevent the onset of the disease and reduce the severity of the symptoms once the disease has progressed.

Herbal medicines have been used for thousands of years in a wide variety of cultures to treat inflammatory disease. A re-examination of traditional medicines for the treatment of inflammation and rheumatic conditions is an attractive prospect as the antiseptic qualities of medicinal plants have also been long recognised and recorded. Furthermore, there has recently been a revival of interest in herbal medications due to a perception that there is a lower incidence of adverse reactions to plant preparations compared to synthetic pharmaceuticals. Antimicrobial plant extracts with high antioxidant contents are particularly attractive as they may treat the symptoms of inflammation as well as blocking the microbial trigger and thus have pleuripotent effects.

Terminalia ferdinandiana is an endemic Australian plant which has been reported to have an extremely high antioxidant content. ${ }^{17,18}$ Furthermore, it was reported that the fruit of this plant also has the highest ascorbic acid levels of any plant in the world, with levels reported as high as $6 \%$ of the recorded wet weight ${ }^{19,20}$ This is approximately 900 times higher $(\mathrm{g} / \mathrm{g})$ than the ascorbic acid content in blueberries (which were used as a standard). As a further comparison, oranges and grapefruit (which are considered good sources of ascorbic acid) only contain approximately $0.007 \%$ wet weight $(0.5 \%$ dry weight $) .{ }^{21}$

Terminalia ferdinandiana has strong antibacterial activity against an extensive panel of bacteria. In a recent study, solvent extracts of various polarities were tested against both Gram positive and Gram negative bacteria. ${ }^{22}$ The polar extracts proved to be more effective antibacterial agents, indicating that the antibacterial components were polar compounds. Indeed, the polar extracts inhibited the growth of nearly every bacteria tested. Both Gram positive and Gram negative bacteria were susceptible, indicating that the inhibitory compounds readily crossed the Gram negative cell wall.

Several studies have reported that high levels of vitamin C may inhibit eukaryotic cell death due to inhibition of oxidative stress. ${ }^{23,24}$ Whilst similar studies are lacking for prokaryotic cells, it is possible that vitamin $\mathrm{C}$ may also have a protective effect, antagonising the antibacterial action of the extracts and protecting against bacterial cell death. Thus, whilst potent antibacterial activity has previously been reported for Kakadu plum fruit, ${ }^{22}$ the growth inhibition may be more pronounced in extracts with lower vitamin $\mathrm{C}$ levels. The current study was undertaken to test the ability of Kakadu plum leaf extracts to inhibit the growth of bacterial associated with autoimmune inflammatory diseases.

\section{MATERIALS AND METHODS}

\section{Plant source and extraction}

T. ferdinandiana leaves were obtained from David Bohme of Northern Territory Wild Harvest, Australia. The leaves were thoroughly dried in a Sunbeam food dehydrator and the dried plant materials were subsequently stored at $-30^{\circ} \mathrm{C}$. Prior to use, the plant materials were thawed and freshly ground to a coarse powder. Individual $1 \mathrm{~g}$ quantities of the ground leaves were weighed into separate tubes and $50 \mathrm{ml}$ of methanol, water, ethyl acetate, chloroform or hexane were added. All solvents were obtained from Ajax and were AR grade. The ground leaveswere individually extracted in each solvent for 24 hours at $4{ }^{\circ} \mathrm{C}$ with gentle shaking. The extracts were subsequently filtered through filter paper (Whatman No. 54) under vacuum, followed by drying by rotary evaporation in an Eppendorf concentrator 5301. 


\begin{tabular}{|c|c|c|c|c|c|c|}
\hline Disease & Bacterial Trigger & $\begin{array}{l}\text { Bacterial } \\
\text { Antigen }\end{array}$ & $\begin{array}{l}\text { Bacterial } \\
\text { Sequence }\end{array}$ & Host Antigen & $\begin{array}{l}\text { Host } \\
\text { Sequence }\end{array}$ & References \\
\hline \multirow[t]{2}{*}{$\begin{array}{l}\text { Rheumatoid } \\
\text { arthritis }\end{array}$} & $\begin{array}{l}\text { Proteus mirabilis } \\
\text { and possibly also }\end{array}$ & haemolysin & ESRRAL & $\begin{array}{l}\text { MHC class } 2 \text { allele } \\
\text { HLA-DR4 }\end{array}$ & EQ/KRRAA & $3,4,8,9$ \\
\hline & other Proteus spp. & urease & IRRET & type XI collagen & LRREI & 8,10 \\
\hline \multirow[t]{3}{*}{$\begin{array}{l}\text { Ankylosing } \\
\text { spondylitis }\end{array}$} & $\begin{array}{l}\text { Klebsiella } \\
\text { pneumoniae }\end{array}$ & $\begin{array}{l}\text { nitrogenase } \\
\text { reductase } \\
\text { enzyme }\end{array}$ & QTDRED & $\begin{array}{l}\text { MHC class } 1 \text { allele } \\
\text { HLA-B27 }\end{array}$ & QTDRED & 3,11 \\
\hline & & pullulanase & DRDE & $\begin{array}{l}\text { MHC class } 1 \text { allele } \\
\text { HLA-B27 }\end{array}$ & DRED & 12 \\
\hline & & pullulanase & GxP & $\begin{array}{l}\text { types I, III and IV } \\
\text { collagen }\end{array}$ & GxP & 13 \\
\hline \multirow[t]{4}{*}{ Multiple sclerosis } & $\begin{array}{l}\text { Pseudomonas } \\
\text { aeriginosa }\end{array}$ & y-CMLD & TRHAYG & $\begin{array}{l}\text { Myelin-neuronal } \\
\text { antigen MBP }\end{array}$ & SRFSYG & 14 \\
\hline & Acinetobacter spp. & 4-CMLD & SRFAYG & $\begin{array}{l}\text { Myelin-neuronal } \\
\text { antigen MBP }\end{array}$ & SRFSYG & 14 \\
\hline & & 3-ОАСТ-А & LTRAGK & $\begin{array}{l}\text { Myelin-neuronal } \\
\text { antigen MOG }\end{array}$ & LYRDGK & 14 \\
\hline & & $\begin{array}{l}\text { Acinetobacter } \\
\text { regulatory } \\
\text { protein }\end{array}$ & *KKVEEI & $\begin{array}{l}\text { Neurofilament-M } \\
\text { protein }\end{array}$ & *KKVEEI & $14-16$ \\
\hline
\end{tabular}

The resultant dry extract was weighed and redissolved in $10 \mathrm{ml}$ deionised water.

\section{Qualitative phytochemical studies}

Phytochemical analysis of the $T$. ferdinandiana leaf extracts for the presence of saponins, phenolic compounds, flavonoids, polysteroids, triterpenoids, cardiac glycosides, anthraquinones, tannins and alkaloids was conducted by previously described assays. ${ }^{25-27}$

\section{Antioxidant capacity determination}

The antioxidant capacity of each sample was assessed using the DPPH free radical scavenging method ${ }^{28}$ with modifications. Briefly,DPPH solution was prepared fresh each day as a $400 \mu \mathrm{M}$ solution by dissolving DPPH (Sigma) in AR grade methanol (Ajax, Australia). The initial absorbance of the DPPH solution was measured at $515 \mathrm{~nm}$ using a Molecular Devices, Spectra Max M3 plate reader and did not change significantly throughout the assay period. A $2 \mathrm{ml}$ aliquot of each extract was evaporated and the residue resuspended in $2 \mathrm{ml}$ of methanol.Each extract was added to a 96-well plate in amounts of 5, 10, 25, 50, $75 \mu \mathrm{l}$ in triplicate. Methanol was added to each well to give a volume of $225 \mu \mathrm{l}$. A volume of $75 \mu \mathrm{l}$ of the fresh DPPH solution was added to each well for a total reaction volume of $300 \mu \mathrm{l}$. A blank of each extract concentration, methanol solvent, and DPPH was also performed in triplicate.Ascorbic acid was prepared fresh and examined across the range $0-25 \mu \mathrm{g}$ per well as a reference and the absorbance's were recorded at 515.All tests were performed in triplicate and triplicate controls were included on each plate. The antioxidant capacity based on DPPH free radical scavenging ability was determined for each extract and expressed as $\mu \mathrm{g}$ ascorbic acid equivalents per gram of original plant material extracted.

\section{Antibacterial screening}

\section{Test microorganisms}

All media was supplied by Oxoid Ltd. Reference strains of Acinetobacter baylyi (ATCC33304), Klebsiella pneumoniae (ATCC31488), Proteus mirabilis (ATCC21721), Proteus vulgaris (ATCC21719) and Pseudomonas aeruginosa (ATCC39324) were purchased from American Tissue Culture Collection, USA.All other clinical microbial strains were obtained from the School of Natural Sciences teaching laboratory, Griffith University. All stock cultures were subcultured and maintained in nutrient broth at $4{ }^{\circ} \mathrm{C}$.

\section{Evaluation of antimicrobial activity}

Antimicrobial activity of all plant extracts was determined using a modified disc diffusion assay. ${ }^{29-32}$ Briefly, $100 \mu \mathrm{l}$ of the test bacteria were grown in $10 \mathrm{ml}$ of fresh nutrient broth media until they reached a count of approximately $10^{8}$ cells $/ \mathrm{ml}$. An amount of $100 \mu \mathrm{l}$ of bacterial suspension was spread onto nutrient agar plates.The extracts were tested for antibacterial activity using $5 \mathrm{~mm}$ sterilised filter 
paper discs. Discs were impregnated with $10 \mu \mathrm{l}$ of the test sample, allowed to dry and placed onto inoculated plates. The plates were allowed to stand at $4{ }^{\circ} \mathrm{C}$ for 2 hours before incubation with the test microbial agents.Plates inoculated with the bacterial species Klebsiella pneumoniae, Proteus mirabilis, Proteus vulgaris andPsendomonas aeuroginosa, were incubated at $30{ }^{\circ} \mathrm{C}$ for 24 hours, then the diameters of the inhibition zones were measured in millimetres. Plates inoculated with Acinetobacter baylyi, were incubated at $37^{\circ} \mathrm{C}$ for 24 hours, then the diameters of the inhibition zones were measured. All measurements were to the closest whole millimetre. Each antimicrobial assay was performed in at least triplicate. Mean values $( \pm$ SEM) are reported in this study. Standard discs of ampicillin $(2 \mu \mathrm{g})$ were obtained from Oxoid Ltd. and served as positive controls for antibacterial activity. Filter discs impregnated with $10 \mu$ l of distilled water were used as a negative control.

\section{Minimum inhibitory concentration (MIC) determination}

The minimum inhibitory concentration (MIC) of the extracts were determined as previously described. ${ }^{33,34}$ Briefly, the plant extracts were diluted in deionised water and tested across a range of concentrations. Discs were impregnated with $10 \mu \mathrm{l}$ of the test dilutions, allowed to dry and placed onto inoculated plates. The assay was performed as outlined above and graphs of the zone of inhibition versus concentration were plotted for each extract. Linear regression was used to calculate the MIC values.

\section{Toxicity screening}

\section{Reference toxin for toxicity screening}

Potassium dichromate $\left(\mathrm{K}_{2} \mathrm{Cr}_{2} \mathrm{O}_{7}\right)$ (AR grade, Chem-Supply, Australia) was prepared as a $1.6 \mathrm{mg} / \mathrm{mlsolution}$ in distilled water and was serially diluted in artificial seawater for use in the Artemia franciscana nauplii bioassay.

\section{Artemia franciscana nauplii toxicity screening}

Toxicity was tested using a modified Artemia franciscana nauplii lethality assay. ${ }^{35-37}$ Briefly, $400 \mu \mathrm{l}$ of seawater containing approximately 47 (mean 47.6, $\mathrm{n}=128$, SD 14.9) A. franciscana nauplii were added to wells of a 48 well plate and immediately used for bioassay. A volume of $400 \mu$ of diluted plant extracts or the reference toxin were transferred to the wells and incubated at $25 \pm 1^{\circ} \mathrm{C}$ under artificial light (1000 Lux). A negative control (400 $\mu$ l seawater) was run in triplicate for each plate. All treatments were performed in at least triplicate. The wells were checked at regular intervals and the number of dead counted. The nauplii were considered dead if no movement of the appendages was observed within 10 seconds. After 24h all nauplii were sacrificed and counted to determine the total $\%$ mortality per well. The LC50 with 95\% confidence limits for each treatment was calculated using probit analysis.

\section{Statistical analysis}

Data are expressed as the mean \pm SEM of at least three independent experiments.

\section{Non-targeted HPLC-MS/MS QTOF analysis}

Chromatographic separations were performed as previously described. ${ }^{28}$ Briefly, $2 \mu \mathrm{L}$ of each sample was injected onto an Agilent 1290 HPLC system fitted with a Zorbax Eclipse plus C18 column (2.1 x $100 \mathrm{~mm}, 1.8 \mu \mathrm{m}$ particle size). The mobile phases consisted of (A) ultrapure water and (B) $95: 5$ acetonitrile/water at a flow rate of $0.7 \mathrm{~mL} / \mathrm{min}$. Both mobile phases were modified with $0.1 \%$ (v/v) glacial acetic acid for mass spectrometry analysis in positive mode and with $5 \mathrm{mM}$ ammonium acetate for analysis in negative mode. The chromatographic conditions utilised for the study consisted of the first 5 min run isocratic ally at 5\% B, a gradient of (B) from 5\% to 100\% was applied from 5 min to $30 \mathrm{~min}$, followed by $3 \mathrm{~min}$ isocratic ally at $100 \%$. Mass spectrometry analysis was performed on an Agilent 6530 quadrapole time-of-flight spectrometer fitted with a Jetstream electrospray ionisation source in both positive and negative mode.

Data was analysed using the Mass hunter Qualitative analysis software package (Agilent Technologies). Blanks using each of the solvent extraction systems were analysed using the Find by Molecular Feature algorithm in the software package to generate a compound list of molecules with abundances greater than 10,000 counts. This was then used as an exclusion list to eliminate background contaminant compounds from the analysis of the extracts. Each extract was then analysed using the same parameters using the Find by Molecular Feature function to generate a putative list of compounds in the extracts. Compound lists were then screened against three accurate mass databases; a database of known plant compounds of therapeutic importance generated specifically for this study (650 compounds); the Metlin metabolomics database (24,768 compounds); and the Forensic Toxicology Database by Agilent Technologies (7,509 compounds). Empirical formula for unidentified compounds was determined using the Find Formula 
function in the software package.

\section{RESULTS}

Liquid extraction yields and qualitative phytochemical screening

Extraction of $1 \mathrm{~g}$ of dried T. ferdinandiana leaves with various solvents yielded dried plant extracts ranging from $59 \mathrm{mg}$ (ethyl acetate extract) to $471 \mathrm{mg}$ (water extract) (Table 2). Deionised water and methanol gave relatively high yields of dried extracted material, whilst all other solvents extracted lower masses. The dried extractswere resuspended in $10 \mathrm{ml}$ of deionised water resulting in the extract concentrations shown in Table 2.

Qualitative phytochemical studies (Table 2) showed that methanol and water extractedthe widest range of phytochemicals.Both showed high levels of phenolics (both water soluble and insoluble phenolics)and tannins, as well as well as high to moderate to high levels of cardiac glycosides, saponins and flavonoids. Triterpenes and anthraquinones were also present in low levels in both extracts and alkaloids were detetected in the methanol extract. The ethyl acetate extract also had high levels of phenolics and moderate levels of flavonoids and tannins. Only low levels of phenolics, flavonoids and tannins were detected in the chloroform and hexane extracts.

\section{Antioxidant content}

Antioxidant capacity (expressed as ascorbic acid equivalence) for the T. ferdinandiana leaf extracts are shown in (Table 2). The antioxidant capacity ranged from a low of $0.4 \mathrm{mg}$ ascorbic acid equivalence per gram of dried plant material extracted (hexane extract) to a high of $340 \mathrm{mg}$ ascorbic acid equivalence per gram of dried plant material extracted (aqueous extract).Whilst significantly lower than the aqueous extract, the methanolic extract also had a high antioxidant capacity with $150 \mathrm{mg}$ ascorbic acid equivalence per gram of dried plant material extracted (aqueous extract).

\section{Antimicrobial activity}

To determine the antimicrobial activity of the crude plant extracts, aliquots $(10 \mu \mathrm{l})$ of each extract were tested in the disc diffusion assay against a panel of bacteria previously identified as microbial triggers of autoimmune inflammatory diseases. Both reference and clinical strains of Proteus mirabilis were strongly inhibited by the methanol, water and ethyl acetate T. ferdinandiana leaf extracts (Figure 1). Indeed, the methanol extract inhibited 8 P. mirabilis growth of both strains more effectively than the ampicillin control, with zones of inhibition of $>17.5 \mathrm{~mm}$ against both strains(compared to approximately $14 \mathrm{~mm}$ for the ampicillin control). The methanol, water and ethyl acetate extracts also inhibited P. vulgaris growth (Figure 2), with zones of inhibition of up to $15 \mathrm{~mm}$ (for the ethyl acetate extract), compared to $7 \mathrm{~mm}$ for the ampicillin control.

The methanol and ethyl acetate extracts (but not the water extract) were similarly potent inhibitors of $K$. pnuemoniae growth (Figure 3). In general, the clinical strain was significantly more susceptible to the extracts, with the inhibition zone of the clinical K. pneumonia being nearly $3 \mathrm{~mm}$ greater than for the ATCC reference strain. Whilst zones of inhibition were also noted for the water, chloroform and hexane extracts, these were only $6 \mathrm{~mm}$ in diameter, indicating that the anti-Klebsiella compounds in these extractswere weak, in low concentrations and/ or nonpolar.

In contrast(with the exception of the water extract), the $A$. baylyi reference strain was significantly more susceptible to the extracts than was the clinical strain (as determined by the zones of inhibition) (Figure 4). The methanol extract was the most potent bacterial growth inhibitor, with zones of inhibition of 19 and $16.3 \mathrm{~mm}$ for the reference and clinical strains respectively.The water and ethyl acetate extracts were also potent inhibitors of $A$. baylyi growth with $>10 \mathrm{~mm}$ zones of inhibition.

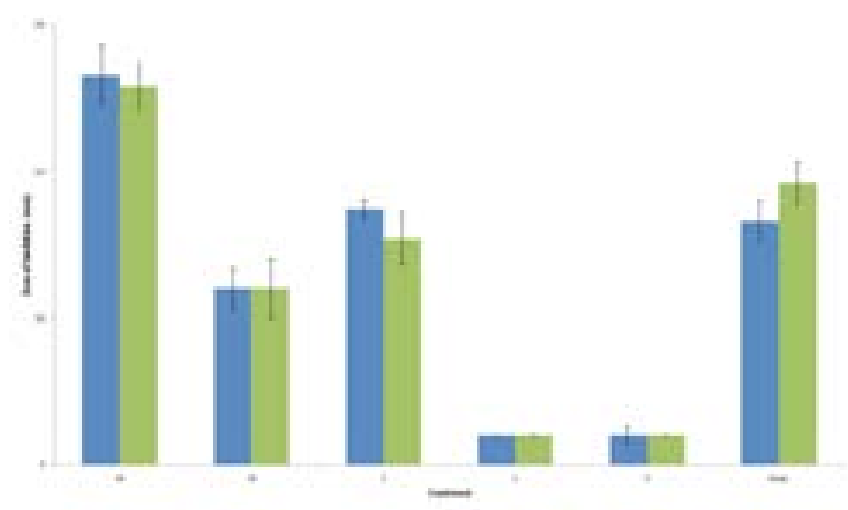

Figure 1: Antibacterial activity of T. ferdinandia leaf extracts against P. mirabilis measured as zones of inhibition ( $\mathrm{mm}$ ). The blue bars represent the inhibitory activity against the reference strain (ATCC: 21721) and the green bars represent the zones of inhibition against the clinical strain. $M=$ methanolic extract; $W=$ water extract; $E=$ ethyl acetate extract; $C=$ chloroform extract; $H=$ hexane extract; Amp $=$ ampicillin $(2 \mu \mathrm{g})$ control. Results are expressed as mean zones of inhibition \pm SEM. 


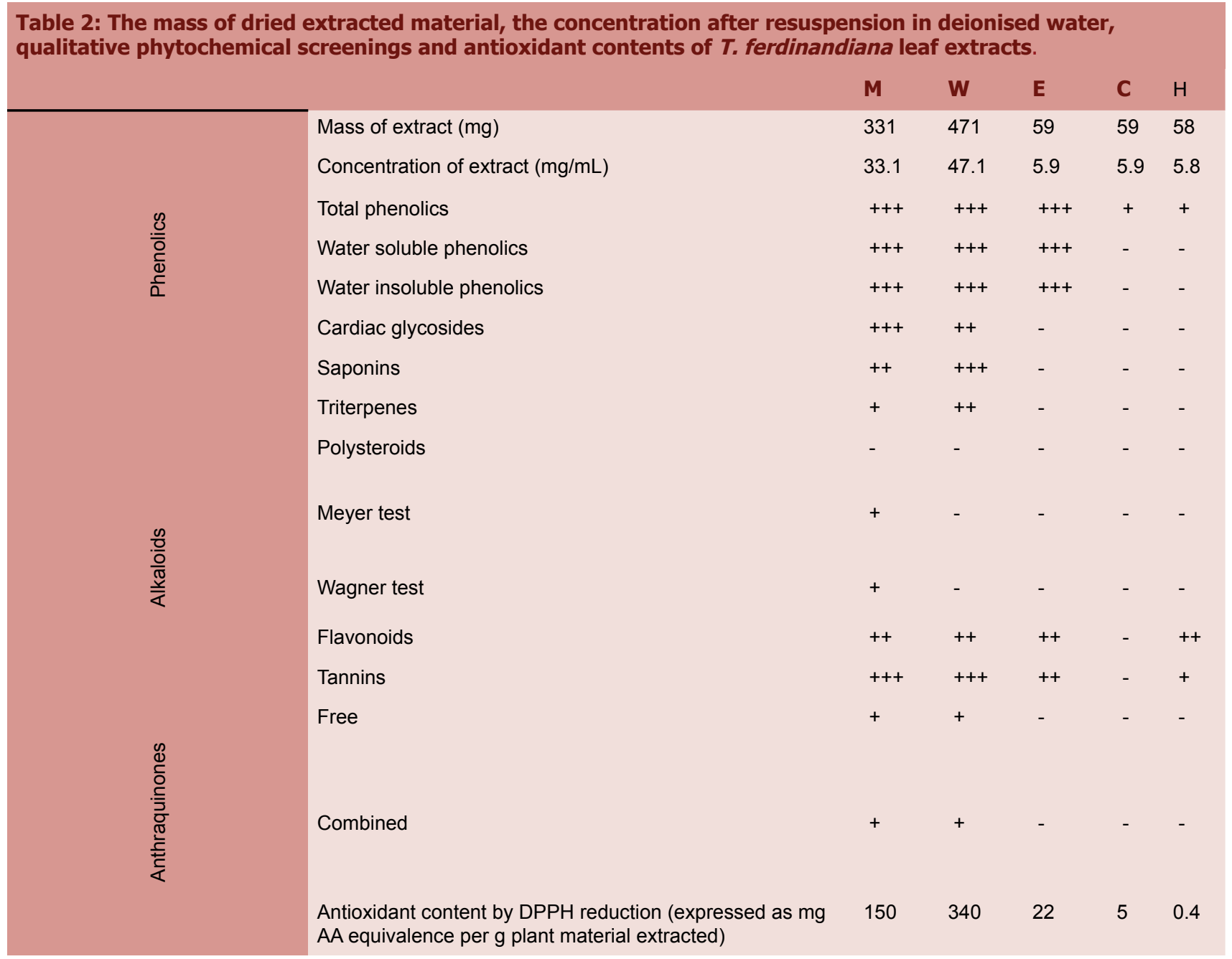

$\mathrm{M}=$ methanolic extract; $\mathrm{W}=$ aqueous extract; $\mathrm{E}=$ ethyl acetate extract; $\mathrm{C}=$ chloroform extract; $\mathrm{H}=$ hexane extract; +++ indicates a large response; ++ indicates a moderate response; + indicates a minor response; - indicates no response in the assay. $A A=$ ascorbic acid.

$P$. aeruginosa growth was also susceptible to the methanol, water and ethyl acetate extracts (Figure 5). The clinical strain was significantly more susceptible to the extracts than was the reference strain. Zones of inhibition of 14.3 and $8.3 \mathrm{~mm}$ were noted for the clinical and reference $P$. aeruginosa strains respectively against the methanol extract. The zones of inhibition for the aqueous and ethyl acetate extracts were approximately 7.5 and $10.5 \mathrm{~mm}$ for the reference and clinical strains respectively.

The antimicrobial efficacy was further quantified by determining the MIC values for each extract against the microbial species which were determined to be susceptible (Table 3). Most of the extracts were effective at inhibiting microbial growth, with MIC values against the susceptible bacteria generally $<1000 \mu \mathrm{g} / \mathrm{ml}(<10 \mu \mathrm{g}$ impregnated in the disc), indicating the potential of these extracts in

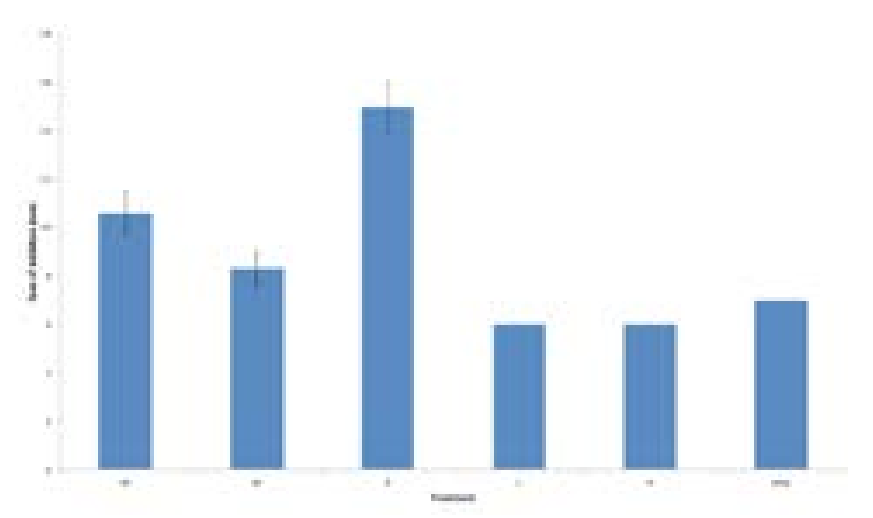

Figure 2: Antibacterial activity of T. ferdinandia leaf extracts against $P$. vulgaris measured as zones of inhibition $(\mathrm{mm}) . M=$ methanolic extract; $W=$ water extract; $E=$ ethyl acetate extract; $C=$ chloroform extract; $H=$ hexane extract; Amp = ampicillin $(2 \mu \mathrm{g})$ control. Results are expressed as mean zones of inhibition $\pm S E M$. 


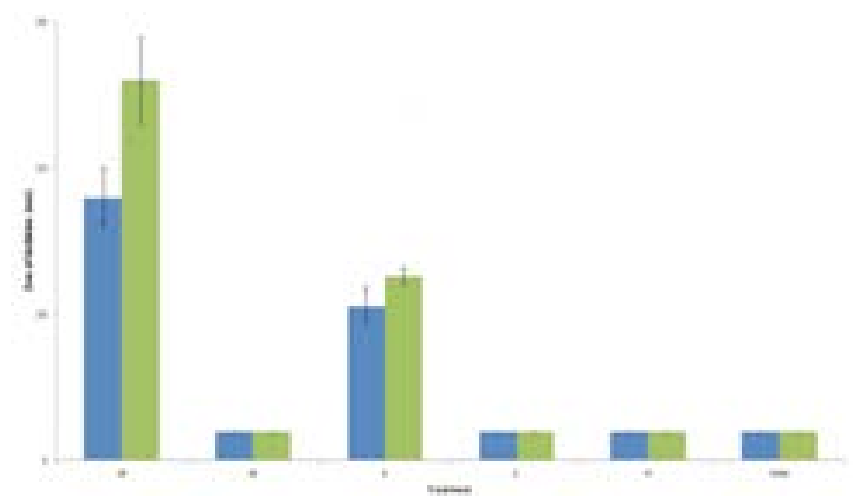

Figure 3: Antibacterial activity of T. ferdinandia leaf extracts against K. pneumoniae measured as zones of inhibition $(\mathrm{mm})$. The blue bars represent the inhibitory activity against the reference strain (ATCC:31488) and the green bars represent the zones of inhibition against the clinical strain. $M=$ methanolic extract; $W=$ water extract; $E=$ ethyl acetate extract; $C=$ chloroform extract; $H=$ hexane extract; Amp $=$ ampicillin $(2 \mu \mathrm{g})$ control. Results are expressed as mean zones of inhibition \pm SEM.

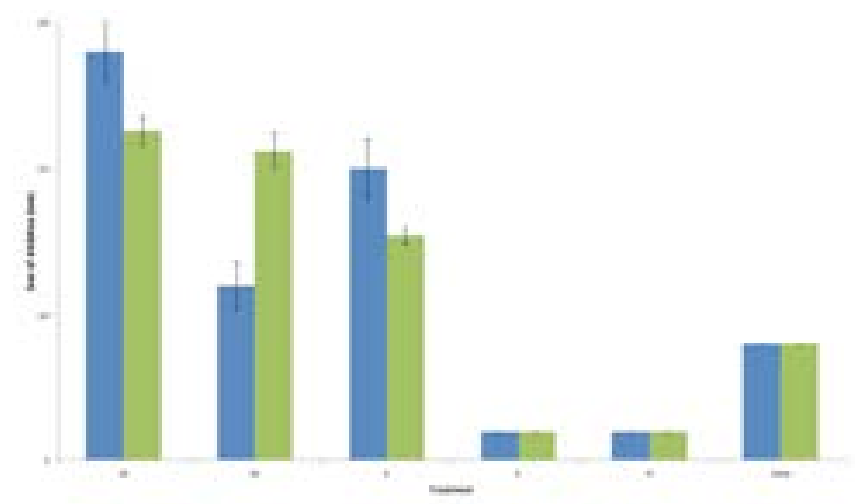

Figure 4: Antibacterial activity of T. ferdinandia leaf extracts against A. baylyi measured as zones of inhibition (mm). The blue bars represent the inhibitory activity against the reference strain (ATCC:33304) and the green bars represent the zones of inhibition against the clinical strain. $M=$ methanolic extract; $W=$ water extract; $E=$ ethyl acetate extract; $C=$ chloroform extract; $H=$ hexane extract; Amp $=$ ampicillin $(2 \mu \mathrm{g})$ control. Results are expressed as mean zones of inhibition $\pm S E M$.

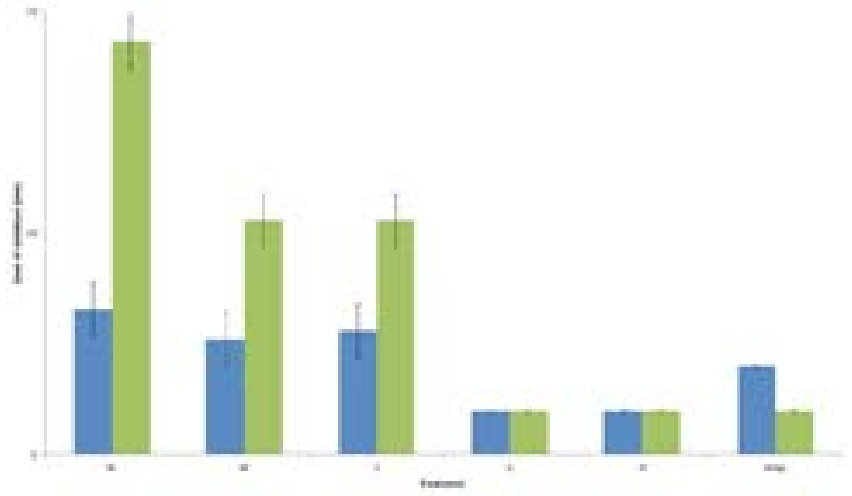

Figure 5: Antibacterial activity of T. ferdinandia leaf extracts against $P$. aeruginosa measured as zones of inhibition ( $\mathrm{mm})$. The blue bars represent the inhibitory activity against the reference strain (ATCC:39324) and the green bars represent the zones of inhibition against the clinical strain. $M=$ methanolic extract; $W=$ water extract; $E=$ ethyl acetate extract; $C=$ chloroform extract; $H=$ hexane extract; Amp $=$ ampicillin $(2 \mu \mathrm{g})$ control. Results are expressed as mean zones of inhibition \pm SEM.

controlling multiple autoimmune inflammatory disorders. The MIC values determined for the ethyl acetate extract were particularly noteworthy, with most MIC values $100-$ $200 \mu \mathrm{g} / \mathrm{ml}(1-2 \mu \mathrm{g}$ impregnated in the disc) against most of the bacterial triggers of autoimmune diseases tested.

\section{Quantification of toxicity}

T. ferdinandia leaf extracts were initially screened at $2000 \mu \mathrm{g} /$ $\mathrm{ml}$ in the assay (Figure 6). For comparison, the reference toxin potassium dichromate $(1000 \mu \mathrm{g} / \mathrm{ml})$ was also tested in the bioassay. The potassium dichromate reference toxin was rapid in its onset of mortality, inducing mortality within the first 3 hours of exposure and 100\% mortality was evident following 4-5 hours (unpublished results). The methanol, water and ethyl acetate extracts also induced significant mortality following $24 \mathrm{~h}$ exposure, indicating that they were toxic at the concentration tested. The chloroform and hexane extracts did not induce mortality

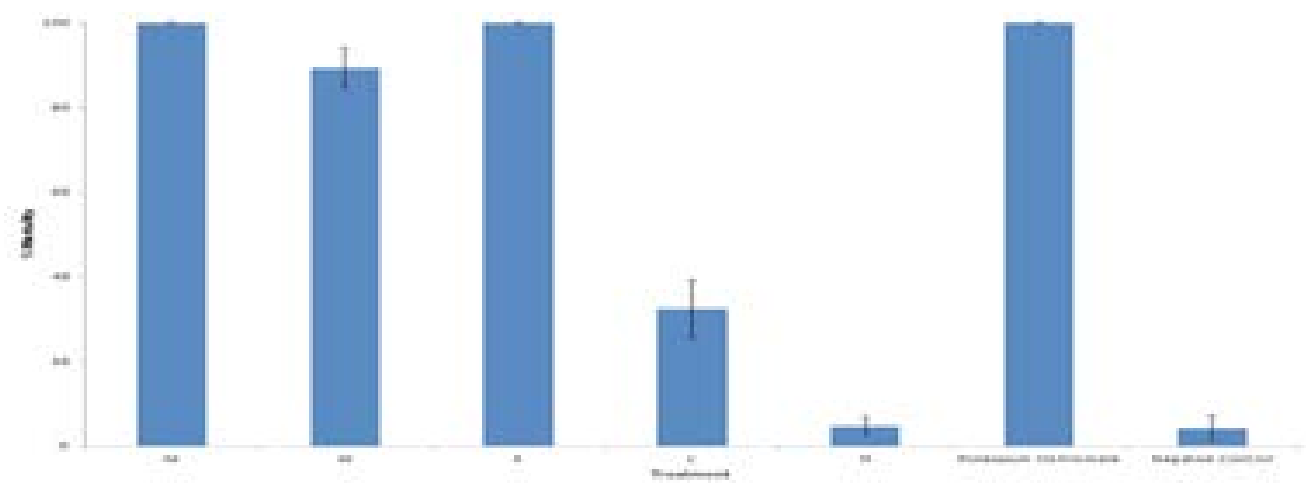

Figure 6: The lethality of T.ferdinandiana leaf extracts $(2000 \mu \mathrm{g} / \mathrm{ml})$ and the potassium dichromate control $(1000 \mu \mathrm{g} / \mathrm{mL})$ towards Artemia nauplii following 24 hours exposure. $M=$ methanolic extract; $W=$ water extract; $E=$ ethyl acetate extract; $C=$ chloroform extract; $H=$ hexane extract. All tests were performed in at least triplicate and the results are expressed as mean $\pm S E M$. 

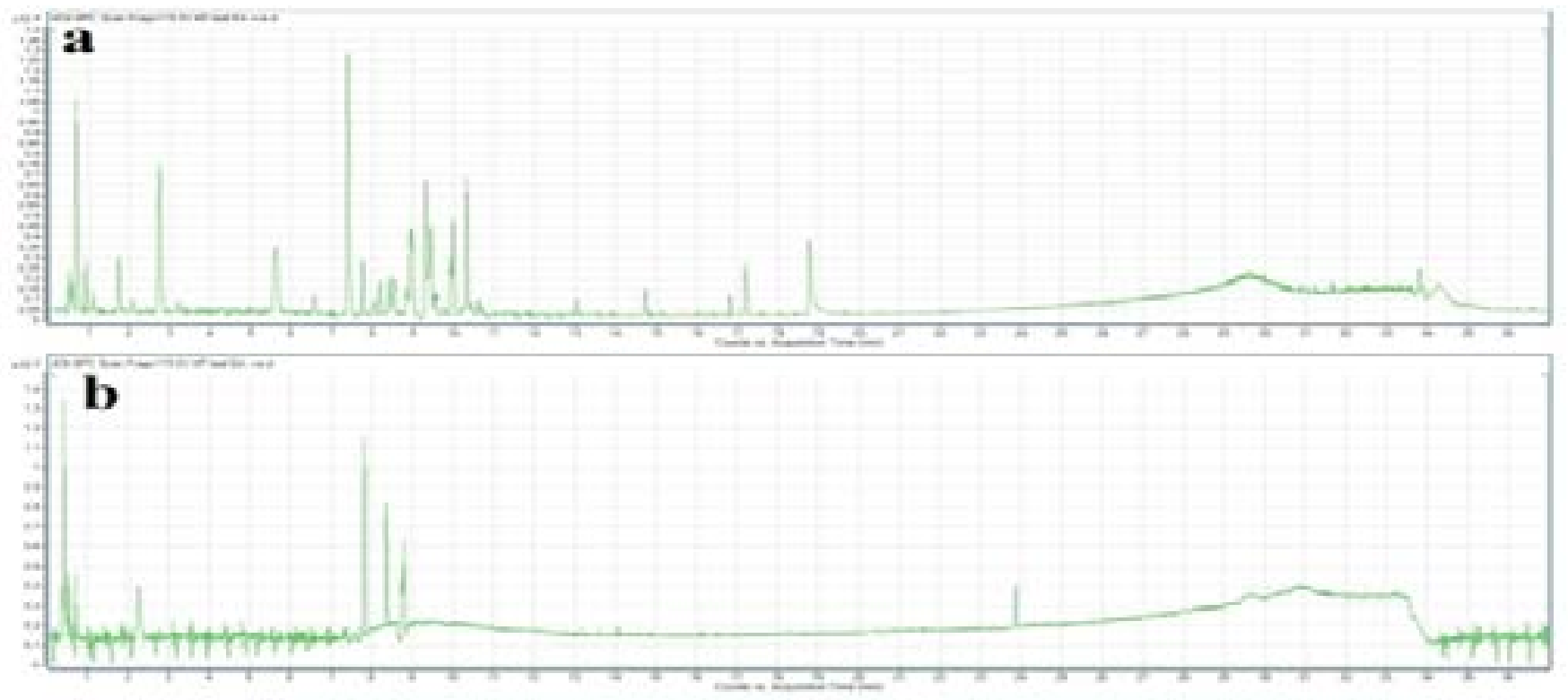

Figure 7:(a) Positive and (b)negative ionRP-HPLC base peak chromatogram (BPC) of 2 ul injections of T.ferdinadniana leaf ethyl acetate extract.

a

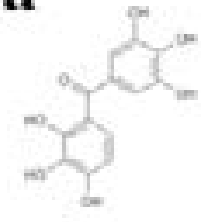

d

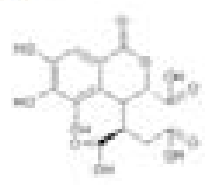

b
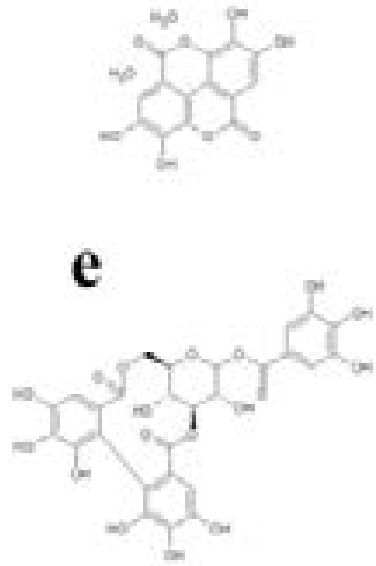

c
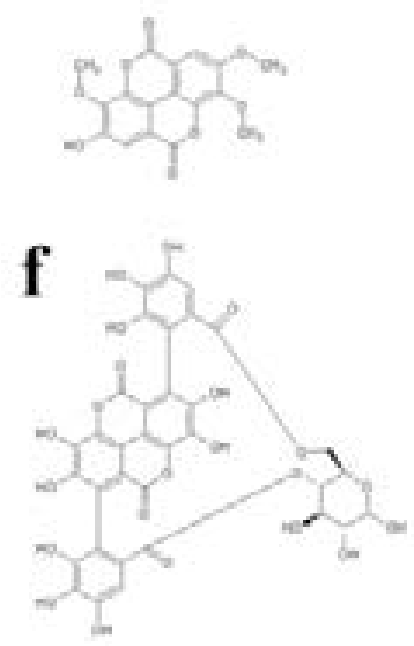

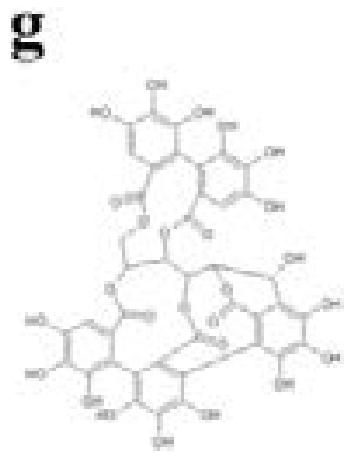

h

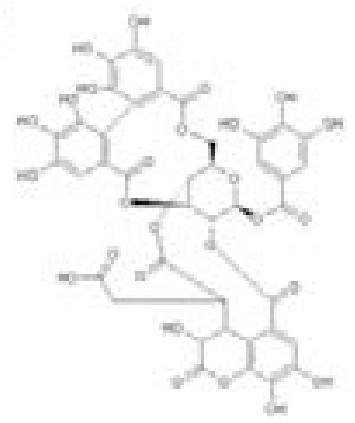

Figure 8: Chemical structures of T. ferdinandiana leaf compounds detected in the ethyl acetate extract: (a) exifone (4-galloylpyrogallol); (b) ellagic acid dehydrate; (c) trimethylellagic acid; (d) chebulic acid; (e) corilagin; (f) punicalin; (g) castalagin; (h) chebulagic acid. 
significantly different to the seawater control and were therefore deemed to be nontoxic.

To further quantify the effect of toxin concentration on the induction of mortality, the extracts were serially diluted in artificial seawater to test across a range of concentrations in the Artemia nauplii bioassay at 24 hours. (Table 3) shows the LC50 values of the T. ferdianadiana leaf extracts towards $A$. franciscana. No LC50 values are reported for The chloroform and hexane extracts as less than $50 \%$ mortality was seen for all concentrations tested. Extracts with an LC50 greater than $1000 \mu \mathrm{g} / \mathrm{ml}$ towards Artemia nauplii have been defined as being nontoxic in this assay. ${ }^{38}$ As only the ethyl acetate extract had a LC50 <1000 $\mu \mathrm{g} /$ $\mathrm{ml}$, all other extracts were considered nontoxic. Whilst the LC50 value for ethyl acetate is below $1000 \mu \mathrm{g} / \mathrm{ml}$, the value of $767 \mu \mathrm{g} / \mathrm{ml}$ indicates low to moderate toxicity.

\section{HPLC-MS/MS analysis}

As the ethyl acetate extract had the greatest antibacterial efficacy (as determined by MIC) yet contained the least extracted material (Table 1), it was deemed the most promising extract for further phytochemical analysis. Optimised HPLC-MS/MS parameters were developed and used to determinethe ethyl acetate extract compound profile. The resultant base peak chromatograms for the positive ion and negative ion chromatograms are presented in (Figure $7 \mathrm{a}$ and $7 \mathrm{~b}$ ) respectively. The negative ion chromatograms had significantly higher background absorbance levels than the positive ion chromatogram, due to ionisation of the reference ions in this mode, possibly masking the signal for some peaks of interest.

The T. ferdinandiana ethyl acetate extract positive ion base peak chromatogram (Figure 7a) revealed numerous peaks, particularly in the early and middle stages of the chromatogram corresponding to the elution of polar compounds.Nearly all of the methanol extract compounds had eluted by 11 minutes (corresponding to approximately $30 \%$ acetonitrile).Indeed, several peaks eluted in the first 1 minute with $5 \%$ acetonitrile. However, several prominent peaks between 13 and $20 \mathrm{~min}$, and a minor peak eluting later in the chromatogram (at nearly $34 \mathrm{~min}$ )indicates the broad spread of polarities of the compounds in this extract.

Qualitative mass spectral analysis of Kakadu plum leaf extracts

In total,63 unique masssignals were noted for the Kakadu plum leaf ethyl acetateextract (Table 4). Putative empirical formulas were achieved for all of these compounds. Of the 63 unique molecular mass signals detected, 42 compounds $(66.7 \%)$ were putatively identified by comparison to the Metlin metabolomics, forensic toxicology (Agilent) and phytochemicals (developed in this laboratory) databases.

\section{DISCUSSION}

Previous studies within our laboratory reported broad spectrum antibacterial activity for $T$. ferdianadiana fruit extracts. ${ }^{22}$ Whilst that study reported potent growth inhibitory properties for the fruit extracts, it did not

\begin{tabular}{|c|c|c|c|c|c|c|}
\hline \multirow{11}{*}{$\begin{array}{l}\frac{\partial}{\vec{E}} \\
\frac{\partial}{\partial} \\
\frac{U}{\Sigma}\end{array}$} & & Methanol & Water & $\begin{array}{l}\text { Ethyl } \\
\text { Acetate }\end{array}$ & Chloroform & Hexane \\
\hline & P. mirabilis (reference strain) & 356 & 925 & 119 & 1571 & 1571 \\
\hline & P. mirabilis (clinical strain) & 494 & 1207 & 119 & 1571 & 1571 \\
\hline & $P$. vulgaris (reference strain) & 734 & 1752 & 188 & 1571 & 1571 \\
\hline & K. pneumoniae (reference strain) & 902 & 4667 & 192 & 1571 & 1571 \\
\hline & K. pneumoniae (clinical strain) & 1352 & 4980 & 164 & 1571 & 1571 \\
\hline & A. baylyi (reference strain) & 780 & 1188 & 125 & 1571 & 1571 \\
\hline & A. baylyi (clinical strain) & 578 & 1779 & 108 & 1571 & 1571 \\
\hline & $P$. aeruginosa (reference strain) & 739 & 1239 & 2733 & 1571 & 1571 \\
\hline & $P$. aeruginosa (clinical strain) & 1020 & 1711 & 2733 & 1571 & 1571 \\
\hline & LC50 (ug/mL) & 1133 & 1330 & 767 & - & - \\
\hline
\end{tabular}


determine the phytochemical(s) responsible for this activity. Whilst much of the phytochemistry of $T$. ferdianadiana has yet to be determined, the high antioxidant capacity and the extremely high levels of ascorbic acid in the fruit have been frequently reported. ${ }^{17,18}$ Indeed, T. ferdinandiana fruit has been reported to have ascorbic acid levels as high as $6 \%$ of the recorded wet weight. ${ }^{19,20}$

The high antioxidant capacity of $T$. ferdinandiana fruit has been postulated as being responsible (at least in part) to potential medicinal properties. ${ }^{39,40}$ In particular, ascorbic acid has been linked to antibacterial, antifungal and antiviral activities, as well as anticancer properties. ${ }^{39,}{ }^{40}$ However, other studies have indicated that ascorbic acid may protect cells from oxidative stress and thus protect against cell death. ${ }^{23,24}$ Whilst those studies examined the effects of ascorbic acid on eukaryotic cells, it is possible that ascorbic acid may have a similar protective effect against bacterial cell death. T. ferdinandiana leaves were examined in the current study in an attempt to minimise the effects of the high ascorbic acid contents present in the fruit.

The leaf extracts examined in this study displayed potent growth inhibitory activity against the bacterial species tested. Indeed, in several cases, we report similar or better antibacterial activities for the T. ferdinandiana leaf extracts compared to those previously reported for the equivalent fruit extracts. ${ }^{22}$ MIC values $<200 \mu \mathrm{g} / \mathrm{ml}$ are reported here for the leaf ethyl acetate extract against a bacterial trigger of ankylosing spondylitis (K. pnuemoniae). In the previous study, no inhibition of $K$. pnuemoniae growth by the fruit ethyl acetate extract was noted, indicating the greater potency of the leaf extract. The leaf ethyl acetate extract was also a much more potent inhibitor of $P$. mirabilis than the fruit ethyl acetate extract reported in the previous study (MIC values of $120 \mu \mathrm{g} / \mathrm{ml}$ and $500 \mu \mathrm{g} / \mathrm{ml}$ respectively).

As the ethyl acetate extract had the most potent antibacterial activity yet the least amount of extracted material, it was deemed the best extract for phytochemical analysis. A total of 63 compounds were detected in the ethyl acetate extract and 44 of these compounds were putatively identified. Of these compounds, 8 were identified as tannins. As well as having a wide diversity of tannin components, the tannins were present as major components. The corilagen, castalagin and the chebulagic acid chromatographic peaks accounted for approximately $11 \%, 1 \%$ and $4 \%$ of the total peak areas respectively for the negative ionisation mode chromatogram (Table 4). Puncialin accounted for approximately $6 \%$ of the total chromatographic peak area in positive ionisation mode, with ellagic acid dehydrate, trimethylellagic acid and chebulic acid combined represent ingapproximately a further $5 \%$ of the total peak area.

It is likely that the high tannin contents in the $T$. ferdinandiana ethyl acetate leaf extract contributes to the inhibitory activity against the microbial triggers of autoimmune inflammatory diseases. Gallotannins including exifone (4-galloylpyrogallol) (Figure 8a) have been reported to inhibit the growth of a broad spectrum of bacterial species ${ }^{41}$ through a variety of mechanisms including binding cell surface molecules including lipotoichoic acid and proline-rich cell surface proteins, ${ }^{42,43}$ and by inhibiting glucosyl transferase enzymes. ${ }^{44}$ Elligitannins are also potent inhibitors of bacterial growth. Ellagic acid dehydrate (Figure 8b), trimethylellagic acid (Figure 8c), chebulic acid (Figure 8d), corilagin (Figure 8e), punicalin (Figure 8f) and castalagin (Figure 8g) have been reported to be highly potent antibiotics, with MIC values as low as $62.5 \mu \mathrm{g} /$ ml. ${ }^{41,45,46}$ Ellagitannins have also been reported to function via several antibiotic mechanisms including interaction with cytoplasmic oxidoreductases and by disrupting bacterial cell walls. ${ }^{41,45}$ Interestingly, the benzopyran tannin chebulagic acid (Figure $8 \mathrm{~h}$ ) has been reported to inhibit a multi-resistant strain of Acinetobacter baumannii, ${ }^{47}$ a species taxonomically related to $A$. baylyi, examined in our study.

It is likely that other phytochemical classes may also contribute to the anti-inflammatory properties of these extracts. Alkaloids, anthraquionones, flavonoids, polyphenolics, phytosterols, saponins, stilbenes and terpenes have also been linked with anti-bacterial activity in different plant species and thus may be responsible (at least in part) for the bacterial growth inhibitory activities reported here. Several terpenoids previously reported in T. ferdinandiana fruit extracts have been reported to suppress NF-kB signaling (the major regulator of inflammatory diseases) ${ }^{48}$ The monoterpenes limonene $e^{49,50}$ and $\alpha$-pinene ${ }^{51}$ have been reported to inhibit NF- $x$ Bsignaling pathways. $\alpha$-Pinene affects inflammation by inhibiting p65 translocation into the nucleus in LPS-induced NF- $x \mathrm{~B}$ signalling. ${ }^{51}$ Furthermore, many other sesquiterpenes and sesquiterpene lactones also have well established anti-inflammatory activities. ${ }^{48}$ Whilst much work is still needed to characterize the mechanisms of action of these compounds, it appears that NF-kB inhibitory activities may be responsible.

Whilst none of these terpenoid compounds were detected in our study, it is possible that they may be present and may contribute to the antibacterial activity of the T. ferdinandiana leaf extracts. Our study examined the phytochemical composition of the extracts using HPLC-MS/MS, whereas the previous studies used GC-MS analysis. Generally, 


\begin{tabular}{|c|c|c|c|c|c|}
\hline \multirow[t]{2}{*}{ Putative identification } & \multirow{2}{*}{$\begin{array}{l}\text { Empirical } \\
\text { formula }\end{array}$} & \multirow{2}{*}{$\begin{array}{l}\text { Molecular } \\
\text { mass }\end{array}$} & \multirow{2}{*}{$\begin{array}{l}\text { Retention } \\
\text { time }\end{array}$} & \multicolumn{2}{|c|}{$\%$ peak area } \\
\hline & & & & $\begin{array}{l}\text { Negative } \\
\text { ionisation } \\
\text { mode }\end{array}$ & $\begin{array}{l}\text { Positive } \\
\text { ionisation } \\
\text { mode }\end{array}$ \\
\hline protocatechuic acid & $\mathrm{C}_{7} \mathrm{H}_{6} \mathrm{O}_{4}$ & 154.0272 & 0.522 & 2.34 & \\
\hline Ethyl 4-hydroxybenzoate & $\mathrm{C}_{9} \mathrm{H}_{10} \mathrm{O}_{3}$ & 166.063 & 0.632 & 0.69 & \\
\hline $\begin{array}{l}\text { (1S,5R)-4-Oxo-6,8-dioxabicyclo } \\
\text { [3.2.1]oct-2-ene-2-carboxylic acid }\end{array}$ & $\mathrm{C}_{7} \mathrm{H}_{6} \mathrm{O}_{5}$ & 170.0219 & 0.417 & 7.22 & \\
\hline Gabapentin & $\mathrm{C}_{9} \mathrm{H}_{17} \mathrm{NO}_{2}$ & 171.126 & 8.996 & & 1.3 \\
\hline shikimic acid & $\mathrm{C}_{7} \mathrm{H}_{10} \mathrm{O}_{5}$ & 174.0539 & 0.395 & 11.54 & \\
\hline 2-tert-Butyl-4-methoxyphenol & $\mathrm{C}_{11} \mathrm{H}_{16} \mathrm{O}_{2}$ & 180.1153 & 14.724 & & 1.18 \\
\hline Mannitol & $\mathrm{C}_{6} \mathrm{H}_{14} \mathrm{O}_{6}$ & 182.0793 & 0.505 & & 0.56 \\
\hline Valdipromide & $\mathrm{C}_{11} \mathrm{H}_{23} \mathrm{NO}$ & 185.1785 & 0.91 & & 1.41 \\
\hline $\begin{array}{l}\text { Benzenemethanol, 2-(2-aminopropoxy) } \\
\text {-3-methyl- }\end{array}$ & $\mathrm{C}_{11} \mathrm{H}_{16} \mathrm{O}_{3}$ & 196.1106 & 9.988 & 1.31 & \\
\hline 11-amino-undecanoic acid & $\mathrm{C}_{11} \mathrm{H}_{23} \mathrm{~N} \mathrm{O}_{2}$ & 201.1734 & 0.691 & & 6.67 \\
\hline jasmonic acid & $\mathrm{C}_{12} \mathrm{H}_{18} \mathrm{O}_{3}$ & 210.1257 & 11.536 & & 0.15 \\
\hline \multirow[t]{2}{*}{ vanilpyruvic acid } & $\mathrm{C}_{10} \mathrm{H}_{10} \mathrm{O}_{5}$ & 210.0529 & 0.632 & 0.58 & \\
\hline & $\mathrm{C}_{9} \mathrm{H}_{6} \mathrm{O}_{7}$ & 226.0117 & 0.871 & 0.59 & \\
\hline \multirow[t]{2}{*}{ Heptylheptanoate } & $\mathrm{C}_{14} \mathrm{H}_{28} \mathrm{O}_{2}$ & 228.2092 & 20.989 & 0.51 & \\
\hline & $\mathrm{C}_{11} \mathrm{H}_{8} \mathrm{O}_{7}$ & 252.0272 & 1.808 & 0.93 & \\
\hline Diprophylline & $\mathrm{C}_{10} \mathrm{H}_{14} \mathrm{~N}_{4} \mathrm{O}_{4}$ & 254.1012 & 0.512 & & 1.5 \\
\hline palmitic acid & $\mathrm{C}_{16} \mathrm{H}_{32} \mathrm{O}_{2}$ & 256.2412 & 23.868 & 3.38 & \\
\hline \multirow[t]{2}{*}{ 2-cyclohexylpiperidine oxalate } & $\mathrm{C}_{13} \mathrm{H}_{23} \mathrm{NO}_{4}$ & 257.1631 & 3.205 & & 0.7 \\
\hline & $\mathrm{C}_{15} \mathrm{H}_{21} \mathrm{~N}_{5}$ & 271.1794 & 7.743 & & 1.66 \\
\hline \multirow[t]{2}{*}{ Exifone } & $\mathrm{C}_{13} \mathrm{H}_{10} \mathrm{O}_{7}$ & 278.0433 & 9.32 & 1 & \\
\hline & $\mathrm{C}_{12} \mathrm{H}_{10} \mathrm{O}_{8}$ & 282.0382 & 0.406 & 0.39 & \\
\hline \multirow{3}{*}{$\begin{array}{l}\mathrm{N} \text {-(2,3-Dimethylphenyl)-1,3,5- } \\
\text { triazaspiro[5.5] undeca-1,4-diene- } \\
\text { 2,4-diamine }\end{array}$} & $\mathrm{C}_{16} \mathrm{H}_{23} \mathrm{~N}_{5}$ & 285.1943 & 4.277 & & 0.56 \\
\hline & $\mathrm{C}_{14} \mathrm{H}_{4} \mathrm{~N}_{4} \mathrm{O}_{4}$ & 292.0228 & 7.434 & & 1.51 \\
\hline & $\mathrm{C}_{14} \mathrm{H}_{4} \mathrm{~N}_{4} \mathrm{O}_{4}$ & 292.0229 & 2.254 & 5.15 & \\
\hline \multirow[t]{2}{*}{ gingerol } & $\mathrm{C}_{17} \mathrm{H}_{26} \mathrm{O}_{4}$ & 294.1836 & 13.017 & 1.25 & \\
\hline & $\mathrm{C}_{17} \mathrm{H}_{25} \mathrm{~N}_{5}$ & 299.211 & 8.158 & & 1.09 \\
\hline \multirow[t]{3}{*}{ TEGASEROD } & $\mathrm{C}_{16} \mathrm{H}_{23} \mathrm{~N}_{5} \mathrm{O}$ & 301.19 & 2.726 & & 9.12 \\
\hline & $\mathrm{C}_{13} \mathrm{H}_{8} \mathrm{O}_{9}$ & 308.017 & 0.751 & 1.04 & \\
\hline & $\mathrm{C}_{14} \mathrm{H}_{4} \mathrm{~N}_{4} \mathrm{O}_{5}$ & 308.0173 & 0.978 & 1.02 & \\
\hline \multirow{2}{*}{$\begin{array}{l}\text { 9,13-dihydroxy-11-octadecenoic } \\
\text { acid }\end{array}$} & $\mathrm{C}_{18} \mathrm{H}_{34} \mathrm{O}_{4}$ & 314.2462 & 20.261 & 0.26 & \\
\hline & $\mathrm{C}_{17} \mathrm{H}_{25} \mathrm{~N} 5 \mathrm{O}$ & 315.2059 & 7.359 & & 15.57 \\
\hline $\begin{array}{l}\left.\text { Naphtho[2", } 3^{\prime \prime}: 4^{\prime}, 5^{\prime}\right] \text { imidazo[2', 1':2,3] } \\
{[1,3] \text { thiazolo[4,5-b]quinoxaline }}\end{array}$ & $\mathrm{C}_{19} \mathrm{H}_{10} \mathrm{~N}_{4} \mathrm{~S}$ & 326.0647 & 0.555 & 1.42 & \\
\hline
\end{tabular}




\begin{tabular}{|c|c|c|c|c|c|}
\hline $\begin{array}{l}\text { 9,12,13-trihydroxy-10,15- } \\
\text { octadecadienoic acid }\end{array}$ & $\mathrm{C}_{18} \mathrm{H}_{32} \mathrm{O}_{5}$ & 328.2251 & 11.03 & 0.25 & \\
\hline ellagic acid dihydrate & $\mathrm{C}_{14} \mathrm{H}_{10} \mathrm{O}_{10}$ & 338.0281 & 1.085 & & 0.77 \\
\hline trimethylellagic acid & $\mathrm{C}_{17} \mathrm{H}_{12} \mathrm{O}_{8}$ & 344.0538 & 14.237 & 1.3 & 0.85 \\
\hline \multirow[t]{2}{*}{ chebulic acid } & $\mathrm{C}_{14} \mathrm{H}_{12} \mathrm{O}_{11}$ & 356.0391 & 0.356 & 1.84 & 2.99 \\
\hline & $\mathrm{C}_{15} \mathrm{H}_{38} \mathrm{~N}_{10} \mathrm{O}_{2}$ & 390.3178 & 29.379 & 3 & \\
\hline Val His Phe & $\mathrm{C}_{20} \mathrm{H}_{27} \mathrm{~N}_{5} \mathrm{O}_{4}$ & 401.2059 & 7.411 & & 0.67 \\
\hline PheLeu His & $\mathrm{C}_{21} \mathrm{H}_{29} \mathrm{~N}_{5} \mathrm{O}_{4}$ & 415.222 & 8.951 & & 5.37 \\
\hline Pro Trp Lys & $\mathrm{C}_{22} \mathrm{H}_{31} \mathrm{~N}_{5} \mathrm{O}_{4}$ & 429.238 & 10.297 & & 4.1 \\
\hline vitexin & $\mathrm{C}_{21} \mathrm{H}_{20} \mathrm{O}_{10}$ & 432.1064 & 9.397 & 0.77 & 5.59 \\
\hline $\begin{array}{l}\text { 1alpha,25-dihydroxy-26,27- } \\
\text { dimethyl-22,22,23,23- } \\
\text { tetradehydro vitamin D3 / } \\
\text { 1alpha,25-dihydroxy-26,27-di }\end{array}$ & $\mathrm{C}_{29} \mathrm{H}_{44} \mathrm{O}_{3}$ & 440.3262 & 6.929 & & 0.14 \\
\hline \multirow[t]{2}{*}{ luteolin } & $\mathrm{C}_{21} \mathrm{H}_{20} \mathrm{O}_{11}$ & 448.1025 & 8.73 & 2.84 & 7.99 \\
\hline & $\mathrm{C}_{21} \mathrm{H}_{12} \mathrm{~N}_{4} \mathrm{O}_{9}$ & 464.0606 & 8.394 & & 4.73 \\
\hline Meclocycline & $\mathrm{C}_{22} \mathrm{H}_{21} \mathrm{Cl} \mathrm{N}_{2} \mathrm{O}_{8}$ & 476.0962 & 13.012 & & 0.78 \\
\hline \multirow[t]{7}{*}{ Chlortetracycline } & $\mathrm{C}_{22} \mathrm{H}_{23} \mathrm{Cl} \mathrm{N} \mathrm{O}_{8}$ & 478.1112 & 9.854 & 0.27 & \\
\hline & $\mathrm{C}_{20} \mathrm{H}_{18} \mathrm{O}_{14}$ & 482.0701 & 0.593 & 0.7 & \\
\hline & $\mathrm{C}_{26} \mathrm{H}_{16} \mathrm{O}_{16}$ & 584.0442 & 2.249 & 0.74 & \\
\hline & $\mathrm{C}_{31} \mathrm{H}_{48} \mathrm{O}_{4}$ & 484.3525 & 4.256 & & 0.66 \\
\hline & $\mathrm{C}_{31} \mathrm{H}_{48} \mathrm{O}_{4}$ & 484.3529 & 6.545 & & 1.18 \\
\hline & $\mathrm{C}_{29} \mathrm{H}_{20} \mathrm{~N}_{4} \mathrm{O}_{10}$ & 584.1174 & 10.667 & & 0.57 \\
\hline & $\mathrm{C}_{28} \mathrm{H}_{14} \mathrm{~N}_{14} \mathrm{O}_{3}$ & 594.1377 & 12.355 & 0.26 & \\
\hline \multirow[t]{2}{*}{$\begin{array}{l}\text { NORSTICTIC ACID } \\
\text { PENTAACETATE }\end{array}$} & $\mathrm{C}_{28} \mathrm{H}_{24} \mathrm{O}_{15}$ & 600.1113 & 9.468 & 0.37 & 0.48 \\
\hline & $\mathrm{C}_{26} \mathrm{H}_{16} \mathrm{~N}_{10} \mathrm{O}_{10}$ & 628.1062 & 14.188 & 0.3 & \\
\hline corilagin & $\mathrm{C}_{27} \mathrm{H}_{22} \mathrm{O}_{18}$ & 634.0819 & 7.803 & 10.74 & 0.69 \\
\hline \multirow{3}{*}{$\begin{array}{l}\text { Diethyl 1,7-bis(2,4-dinitrophenyl)- } \\
\text { 1,7-dihydrodipyrazolo[3,4-b:4',3'-e] } \\
\text { pyrazine-3,5-dicarboxylate }\end{array}$} & $\mathrm{C}_{24} \mathrm{H}_{16} \mathrm{~N}_{10} \mathrm{O}_{12}$ & 636.0976 & 8.345 & 9.67 & \\
\hline & $\mathrm{C}_{23} \mathrm{H}_{16} \mathrm{~N}_{10} \mathrm{O}_{13}$ & 640.0908 & 1.623 & 0.15 & \\
\hline & $\mathrm{C}_{32} \mathrm{H}_{56} \mathrm{~N}_{20}$ & 720.5001 & 31.075 & & 1.2 \\
\hline Diadenosine triphosphate & $\mathrm{C}_{20} \mathrm{H}_{27} \mathrm{~N}_{10} \mathrm{O}_{16} \mathrm{P}_{3}$ & 756.0815 & 11.293 & & 0.41 \\
\hline punicalin & $\mathrm{C}_{34} \mathrm{H}_{22} \mathrm{O}_{22}$ & 782.0621 & 9.363 & & 5.65 \\
\hline castalagin & $\mathrm{C}_{41} \mathrm{H}_{26} \mathrm{O}_{26}$ & 934.0715 & 8.692 & 1.1 & \\
\hline chebulagic acid (isomer 1) & $\mathrm{C}_{41} \mathrm{H}_{30} \mathrm{O}_{27}$ & 954.0957 & 7.654 & 1.32 & \\
\hline chebulagic acid (isomer 2) & $\mathrm{C}_{41} \mathrm{H}_{30} \mathrm{O}_{27}$ & 954.0965 & 9.878 & 2.25 & \\
\hline
\end{tabular}


HPLC-MS/MS is a good choice for metabolomic profiling studies as it detects a larger amount of compounds of varying polarities than does GC-MS. However, HPLC-MS/ MS analysis is limited to studies of the mid-highly polar compounds and is not as useful for studies aimed at highly non-polar compounds. The terpenoids are relatively nonpolar compounds and it is possible that our analysis protocol was unable to detect them. However, this is unlikely as we have used this protocol routinely in our lab and have previously detected low polarity compounds including several of these terpenoids. It is more likely that if present, their levels were below the threshold of detection in our system and that they did not contribute significantly to the potent antibacterial activity reported here.

Our findings also indicate that T. ferdinandiana leaf extracts displayed low toxicity towards Artemia franciscana. Indeed, the methanol, water, chloroform and hexane extracts all had LC50 values well in excess of $1000 \mu \mathrm{g} / \mathrm{ml}$. Only the ethyl acetate extract displayed significant toxicity with an LC50 value of $767 \mu \mathrm{g} / \mathrm{ml}$. As an LC50 of $\geq 1000 \mu \mathrm{g} / \mathrm{ml}$ is defined as nontoxic, ${ }^{38}$ this extract is considered to be of only low to moderate toxicity.

\section{CONCLUSION}

The results of this study demonstrate the potential of $T$. ferdianadiana leaf extracts to block the growth of bacterial species associated with the onset of several autoimmune inflammatory diseases. Thus, T. ferdianadiana leaf extracts have potential in the prevention and treatment of rheumatoid arthritis, ankylosing spondylitis and multiple sclerosis in genetically susceptible individuals. Further studies aimed at the purification and identification of the bioactive components are needed to examine the mechanisms of action of these agents.

\section{ACKNOWLEDGEMENTS}

Financial support for this work was provided by the Environmental Futures Research Institute and the School of NaturalSciences, Griffith University. We are most grateful to David Boehme of NT Wild Harvest for providing the T. ferdianadiana leaves used in this study.

\section{REFERENCES}

1. Lawrence RC, Helmick $\mathrm{CH}$, Arnett FC, Deyo RA, Felson DT, Giannini EH, et al. Estimates of the prevalence of arthritis and selected musculoskeletal disorders in the United States. Arthritis
Rheum. 1998; 41(5): 778-7.

2. Alataha D, Kapral T, Smolen JS. Toxicity profiles of traditional disease modifying antirheumatic drugs for rheumatoid arthritis. Ann Rheum Dis. 2003; 62(5): 482-6.

3. Ebringer A, Rashid T. Rheumatoid arthritis is an autoimmune disease triggered by Proteus urinary tract infection. Clin Develop Immunol. 2006; 13(1): 41-8.

4. Ebringer A, Cunningham P, Ahmadi K, Wrigglesworth J, Hosseini $\mathrm{R}$, Wilson C. Sequence similarity between HLA-DR1 and DR4 subtypes associated with rheumatoid arthritis and Proteus/Serratia membrane haemolysins. Ann Rheum Dis. 1992; 51(11): 1245-6.

5. Hughes LE, Smith PA, Natt RS, et al. Cross-reactivity between related sequences found in Acinetobacter sp., Pseudomonas aeruginosa, myelin basic protein and myelin oligodendrocyte glycoprotein in multiple scherosis. J Neuroimmunol. 2003; 144(1): 105-15.

6. Beermann $\mathrm{C}$, Wunderli-Allenspach $\mathrm{H}$, Groscurth $\mathrm{P}$, et al. Lipoproteins from Borrelia burgdorferi applied in liposomes and presented to dendritic cells induce $\mathrm{CD}^{+} \mathrm{T}$-lymphocytes in vitro. Cell Immunol. 2000; 20(12): 124-31.

7. Kollef MH, West S, Davis DR, et al. Central and peripheral nervous system demyelination after infection with Mycoplasma pneumoniae. Evidence of an autoimmune process. Southern Med J. 1991; 84(10): 1255-8.

8. Cock I, van Vuuren SF. Anti-Proteus activity of some South African medicinal plants: their potential for the prevention of rheumatoid arthritis. Inflammopharmacology. 2014; 22(1): 23-36. doi:10.1007/ s10787-013-0179-3

9. Nepom GT, Byers P, Seyfried C, Healey LA, Wilske KR, Stage $D$, et al. HLA genes associated with rheumatoid arthritis. Arthritis Rheum. 1989; 32(1): 15-21.

10. Wilson C, Ebringer A, Ahmadi K, Wrigglesworth J, Tiwana H, Fielder $\mathrm{M}$, et al. Shared amino acid sequences between major histocompatibility complex class II glycoproteins, type XI collagen and Proteus mirabilis in rheumatoid arthritis. Ann Rheum Dis. 1995; 54(3): 216-20.

11. Schwimmbeck PL, Yu DTY, Oldstone MBA. Autoanti-bodies to HLA-B27 in the sera of HLA-B27 patients with ankylosing spondylitis and Reiter's syndrome: molecular mimicry with Klebsiella pneumoniae as a potential mechanism of autoimmune disease. J Exp Med. 1987; 166(1): 173-81.

12. Ebringer $A$, Rashid $T$, Wilson $C$ et al. Ankylosing spondylitis as an auto-immune disease linked to intestinal Klebsiella infection: prospects for a new therapeutic approach. Curr Rheum Rev. 2006; 2(1): 55-68.

13. Fielder M, Pirt SJ, Tarpey I et al. Molecular mimicry and ankylosing spondylitis: possible role of a novel sequence in pullulanase of Klebsiella pneumoniae . FEBS Lett. 1995; 369(2): 243-8.

14. Ebringer $A$, Hughes $L$, Rashid T, Wilson $C$. Acinetobacter immune response in multiple sclerosis. Etiopathogenetic role and its possible use as a diagnostic marker. JAMA Neurol. 2005; 62(1): 33-6.

15. Ebringer A, Rashid T, Wilson C. The role of Acinetobacter in the pathogenesis of multiple sclerosis examined by using Popper sequences. Med Hypoth. 2012; 78(6): 763-9.

16. Rashid T, Ebringer A. Autoimmunity in rheumatic diseases is induced by microbial infections via cross reactivity or molecular mimicry. Autoimmune Dis 2012; 2012: Article ID 539282: DOI: $10.1155 / 2012 / 539282$.

17. Netzel M, Netzel G, Tian Q, Schwartz S, Konczak I. NativeAustralian fruits - a novel source of antioxidants for food. Innov Food Sci Emerg Technol. 2007; 8(3): 339-46.

18. Konczak I, Zabaras D, Dunstan M, Aguas P. Antioxidant capacityand hydrophilic phytochemicals in commercially grown Australian fruits. Food Chem. 2010; 123(4): 1048-54. 
19. Woods B. A study of the intra-specific variations and commercial potenatial of Terminalia fredinandiana (the Kakadu Plum). MScthesis, Northern Territory University, Australia; 1995.

20. Miller JB, James KW, Maggiore PM. Tables of composition of Australian Aboriginal foods. Aboriginal Studies Press; 1993. 256.

21. Johnson PD. Acerola (Malpighiaglabra L., M. punicifolia L., M. Emarginata D.C.): agriculture, production and nutrition. World Rev Nutr Diet. 2003; 91 67-75.

22. Cock IE, Mohanty S. Evaluation of the antibacterial activity and toxicity of Terminalia ferdinandia fruit extracts. Pharmacog Journal. 2011; 3(20): 72-9.

23. Montecinos V, Guzmán $P$, Barra V, Villagrán $M$ et al. Vitamin $C$ is an essential antioxidant that enhances survival of oxidatively stressed human vascular endothelial cells in the presence of a vast molar excess of glutathione. J Biol Chem. 2007; 282(1): 15506-15.

24. Guaiquil VH, Vera JC, Golde DW. Mechanism of vitamin C inhibition of cell death induced by oxidative stress in glutathione-depleted HL-60 cells. J Biol Chem. 2001; 76 (44): 40955-61.

25. Vesoul J, Cock IE. An examination of the medicinal potential of Pittosporum phylloraeoides: Toxicity, antibacterial and antifungal activities. Pharmacog Commn. 2011; 1(2): 8-17.

26. Boyer H, Cock IE. Evaluation of the potential of Macademia integriflora extracts as antibacterial food agents. Pharmacog Commn. 2013; 3(3): 53-62.

27. Sautron C, Cock IE. Antimicrobial activity and toxicity of Syzygium australe and Syzygium leuhmanii fruit extracts. Pharmacog Commn. 2014; 4(1): 53-60.

28. Arkhipov A, Sirdaarta J, Rayan P, McDonnell PA, Cock IE. An examination of the antibacterial, antifungal, anti-Giardial and anticancer properties of Kigelia Africana fruit extracts. Pharmacog Commn. 2014; 4(3): 62-76.

29. Cock I, Mohanty S, White A, Whitehouse M. Colloidal silver (CS) as an antiseptic: Two opposing viewpoints. Pharmacog Commn. 2012; 2 (1): 49-58.

30. Mohanty S, Cock IE. Bioactivity of Syzygium jambos methanolic extracts: Antibacterial activity and toxicity. Pharmacog Res. 2010; $2(1)$ : 4-9.

31. Kalt FR, Cock IE. GC-MS analysis of bioactive Petalostigma extracts: Toxicity, antibacterial and antiviral activities. Pharmacog Mag. 2014; 10(37 Suppl): S37-48.

32. Winnett V, Boyer H, Sirdaarta J, Cock IE. The potential of Tasmannia lanceolata as a natural preservative and medicinal agent: Antimicrobial activity and toxicity. Pharmacog Commn. 2014; 4 (1): 42-52.

33. Cock IE, Kukkonen L. An examination of the medicinal potential of Scaevola spinescens: Toxicity, antibacterial and antiviral activities. Pharmacog Res. 2011; 3 (2): 85-94.

34. Vesoul J, Cock IE. The potential of Bunya nut extracts as antibacterial functional food agents. Pharmacog Commn. 2012; 2 (1): $72-9$

35. Sirdaarta J, Cock IE. Vitamin E and Trolox ${ }^{\mathrm{TM}}$ reduce toxicity of Aloe barbadensis Miller juice in Artemia franciscana nauplii but individually are toxic at high concentrations. Int J Toxicol. 2008;
$5(1): 1$

36. Ruebhart DR, Wickramasinghe W, Cock IE. Protective efficacy of the antioxidants vitamin $\mathrm{E}$ and Trolox against Microcystis aeruginosa Artemia franciscana and microcystin-LR in Artemia franciscana nauplii. J Toxicol Environ Health Part A. 2009; 72(24): 1567-75

37. Mpala L, Chikowe G, Cock IE. No evidence of antiseptic properties and low toxicity of selected Aloe species. J Pharm Neg Res. 2010; 1(1): 10-6.

38. Cock IE, Ruebhart DR. Comparison of the brine shrimp nauplii bioassay and the ToxScreen-II test for the detection of toxicity associated with Aloe vera (Aloe barbadensis Miller) leaf extract. Pharmacog Res. 2009; 1(2): 102-8.

39. Mohanty S, Cock IE. The chemotherapeutic potential of Terminalia ferdinandiana: Phytochemistry and bioactivity. Pharmacog Rev. 2012; 6 (11): 29-36.

40. Cock IE. The medicinal properties and phyto chemistry of plant of the genus Terminalia (Combretaceae). Progress in Drug Research; 2014: in press.

41. Buzzini P, Arapitsas P, Goretti M, Branda E, Turchetti B, Pinelli $\mathrm{P}$, leri F, Romani A. Antimicrobial activity of hydrolysable tannins. Mini-Reviews Med Chem. 2008; 8(12): 1179-87.

42. Wolinsky LE, Sote EO. Isolation of natural plaque-inhibiting substances from Nigerian chewing sticks. Caries Res 1984 18(3): 216-25.

43. Hogg SD, Embery G. Blood-group-reactive glycoprotein from human saliva interacts with lipoteichoic acid on the surface of Streptococcus sanguis cells. Arch Oral Biol. 1982; 27(3): 261-8.

44. Wu-Yuan CD, Chen CY,Wu RT. Gallotannins inhibit growth, watersoluble glucan synthesis, and aggregation of Streptococci mutans. J Dental Res. 1988; 67:issue missing? 51-5.

45. Machado TP, Pinto AV, Pinto MCFR, Leal ICR, Silva MG, Amaral ACF, et.al. In vitro activity of Brazilian medicinal plants, naturally occurring naphthoquinones and their analogues, against methicillin-resistant Staphylococcus aureus. Internat J Antimicrob Agents. 2003; 21(3): 279-84.

46. Burapadaja S, Bunchoo A. Antimicrobial Activity of Tannins from Terminaliacitrina. Planta Medica. 1995; 61(04): 365-6.

47. Miyasaki Y, Rabenstein JD, Rhea J, Crouch ML, Mocek UM, Emmett Kittell P, et. al. Isolation and characterisation of antimicrobial compounds in plant extracts against multidrugresistant Acinetobacter baumannii. PLoS One. 2013; 8(4): e61594.

48. Salminen A, Lehtonen M, Suuronen T, Kaarniranta K, Huuskonen J. Terpenoids: Natural inhibitors of NF-KB signalling with antiinflammatory and anticancer potential. Cell Molec Life Sci. 2008; 65(19): 2979-9.

49. Lu XG, Zhan LB, Feng BA, Qu MY, Yu LH, Xie JH. Inhibition of growth and metastasis of human gastric cancer implanted in nude mice by d-limonene. World J Gastroenterol. 2004; 10(14): 2140-4.

50. Crowell PL. Prevention and therapy of cancer by dietary monoterpenes. J Nutr. 1999; 129(3): 775S-8S.

51. Zhou JY, Tang FD, Mao GG, Bian RL. Effect of a-pinene on nuclear translocation of NF-kB in THP-1 cells. Acta Pharmacol Sin. 2004; 25(4): 480-4. 